Regional and Business Studies (2020) Vol 12 No 1, 69-79

Kaposvár University, Faculty of Economic Science, Kaposvár

doi: $10.33568 /$ rbs. 2461

\title{
The Applicability of Kapferer’s Brand Adentity Prism in City Branding Through the Example of Kaposvár
}

\author{
Kristóf Kovács \\ Kaposvár University, Faculty of Economic Science, H-7400 Kaposvár Guba S. u. 40
}

\section{ABSTRACT}

Kaposva'r started to consciously build its brand in 2016 when the General Assembly accepted the city branding strategy of the settlement, its management has been trying to refine and clarify the positioning of the Kaposvar brand. Kapferer's prism may make it feasible. This essay makes an attempt to estimate the applicability of brand identity prism on the city branding strategy of Kaposvar, thus exploring the opportunities in city brand positioning provided by Kapferer's method. The paper examines the desirable image of Kaposvar detailed in the strategy from the six aspects of Kapferer's prism, and tries to define the attributes which may strengthen the Kaposvar brand.

Keywords: city branding, brand identity prism, Kaposvár

\section{INTRODUCTION}

Jean-Noel Kapferer elaborated a method with the help of which any brand identity can be measured. His brand identity prism analyses brand identity form six different aspects, in this way it gives a complex but comprehensible diagnosis about its objects. In the last couple of decades, due to the constantly intensifying competition of countries, cities and regions, marketing studies reached geographical entities also, resulting in the evolution of a subfield: regional and settlement marketing. Although Kapferer does not tell a word about cities when talking about his brand identity prism, he refers to its applicability on place brands as he writes: "A [town] brand is therefore a known name with which the audience spontaneously associates positive, attractive and unique values, both tangible (the advantages of living or working there) and intangible (the town's style and heritage, etc)" (Kapferer, 2008). Since Kaposvár started to consciously build its brand in 2016 when the General Assembly accepted the city branding strategy of the settlement, its management has been trying to refine and clarify the positioning of the Kaposvár brand. Kapferer's prism may make it feasible. This essay makes an attempt to estimate the applicability of brand identity prism on the city branding strategy of Kaposvár, thus exploring the opportunities in city brand positioning provided by Kapferer's method. The paper examines the desirable image of Kaposvár detailed in the strategy from the six aspects of Kapferer's prism, and tries to define the attributes which may strengthen the Kaposvár brand. 


\section{LITERATURE REVIEW}

\section{City image as an advantage in the competition of settlements}

While, according to certain authors, the earliest traces of city marketing activity can be found not only decades but centuries ago, branding of settlements means a relatively new area of science, and in the last two decades it underwent an extraordinary evolution. In 2004 Kavaratzis still stated in his thorough literature review that the activities that most of the texts called branding of cities hardly went beyond city marketing (Kavaratzis, 2004). Anholt and Hospers can be considered to be the pioneers of the practice-oriented branding settlement, because - in addition to that they both criticized the use of traditional marketing tools which they called "propagandistic”, in the competition of settlements - they recommended conceptual and actually implemented development of settlements. They pointed out that the complex nature of the place product did not make it possible to manage it as a simple brand: they think that during the formation of the settlement's brand the city's image has to be dealt with, an approach which is just partly similar to that of corporate marketing (Anholt, 2010, Hospers, 2011). A construction of an image requires covering all the positive attributes of the city. But this complexity makes measurability much more complicated (Hankinson, 2015).

\section{A considerable barrier of measurability: the complex nature of place products}

The place product is a combination of several simple services. Since these service providers are often organizationally separate from each other, not surprisingly, the target groups also show a considerable heterogeneity. Thus, these services view their consumer groups, which are frequently the same, from a different starting base. They have very different concepts of quality. (Garamhegyi and Boros, 2009)

As the traditional marketing mix (product, price, place, promotion) interpretations are not applicable directly in city marketing, István Piskóti developed the city marketing toolkit constituted by $2 \mathrm{C}$-s instead of 4 P-s: content competency and communicational competency. Positioning, therefore, has to be made according to the diverse elements of the content competency of the city (Piskóti, 2012).

One of the most complex and still fiercely debated question of city branding is positioning (Garamhegyi, 2004). One of the clearest differences between a traditional product and a product in regional marketing is that the sale of the latter does not result in a transfer of its ownership title (Kozma, 1995). Bearing in that mind, we applied the method of positioning through experience (Janiszewska and Insch, 2012). Strengthening the existing sensuous and cognitive contact between the consumers and the image of the city seems to be the most appropriate way of position the main brand Kaposvár.

Positioning can be built on an only main attraction solely when it is outstanding, remarkable, well-known and profitable enough to function as the focus of the city brand around which sub-brands can be arranged. In the absence of characteristic attraction, any other conceptual consideration may advance the image creation, however, there is a significant danger of undesirable shift in the balance of the branding 
process in this case as well. An ill-chosen direction it can de-emphasize or overshadow the strengths that - remaining excluded from the overstrain mainstream of the branding process - they lose their key role in the brand image and increasingly get out of the potential tourists' sight (Lackó, 1995).

\section{MATERIALS AND METHODS}

Jean-Noël Kapferer's theory offers an opportunity for brand identity and image to be measured. He makes brand identity a central issue in his approach - it expresses the vision of the brand together with its distinctive features, values, competence, recognizable features and the needs that have been able to be met by it. Kapferer's brand identity prism can be described along six dimensions. Each dimension is needed to be treated in order to construct the correct picture of the brand in the consumer's mind (Bauer and Kolos, 2016).

Florek and Janiszewska warn that although the Kapferer's measurement method can perfectly be used for consumer goods brands, its application to place brands is restricted. They point out that "the method's key limitation is its synthetic nature which involves focusing on distinct and unambiguously defined brand areas. In the context of place brands, the abundance of target groups and the complexity of the place product largely hinder adoption of the Brand Prism as a tool for building up a brand identity. The method may prove useful only with reference to small territorial areas focused on a single, narrowly-defined group (e.g. inhabitants) with a strong and clear point of difference" (Florek and Janiszewska, 2013). Nevertheless, brand identity prism can surely make a city brand more coherent as Kaposvár's example detailed below perfectly shows.

This essay was written on the basis analysis of the following surveys previously ordered by the local government: twenty in-depth interviews with experts conducted by Infinit Media Ltd. in the summer of 2015, Tourism Development Plan 2014-2020 made by Ecorys Hungary Ltd. for Kaposvár and the Zselic region Tourist Destination Management Association in September 2014, Research Report about the Image of the Kaposvár and the Zselic region Tourist Destination written by EconoConsult Ltd. in 2011 (EconoConsult, 2011). Besides that, the qualitative analysis uses the City Branding Strategy of Kaposvár from 2016, which contains those main targets that predict the main characteristics of a desirable brand of the settlement.

\section{RESULTS AND DISCUSSION}

\section{Positioning of the Kaposvár brand}

The primary aim of positioning the main brand Kaposvár - and the branding strategy as a whole - is to meet the already existing expectations and demands of the potential target audience. This requires the most suitable and authentic summary of them, which works as a logline of a movie (Papp-Vary, 2017). There is a description about Kaposvár, which can be found on numerous internet blogs - it perfectly synthesizes the mood created by the core values of the city, and reads as follows: 
"The city is the northern gate of the Zselic. One of its most lovely parts is the main street in which you can see beautiful buildings and inviting cafés wherever you turn. Life is brisky and breezy throughout the year, festivals, celebrations, exhibitions, fairs, theatrical performances, carnivals overlap in the calendar, furthermore, museums, private collections, and galleries offer themselves for the lovers of culture. Such a dense concentration of arts is not a new phenomenon at all in the city, the famous painter József Rippl-Rónai was born and lived here, his late residence is a museum today." (Utazok, 2016)

The sub-brands of the main brand Kaposvár are intended to realize each factors of the account above, and build an image of the city, which complies with the description as much as possible. According to the preferences of the target audience, the strategy classified the sub-brands into two brand clusters. These principal categories represent the two primal aspects of the main brand. As shown in Figure 1, the endorsed brands can be divided into two sets: culture and nature (active recreation).

\section{Figure 1}

\section{Structure of the Kaposvár brand}

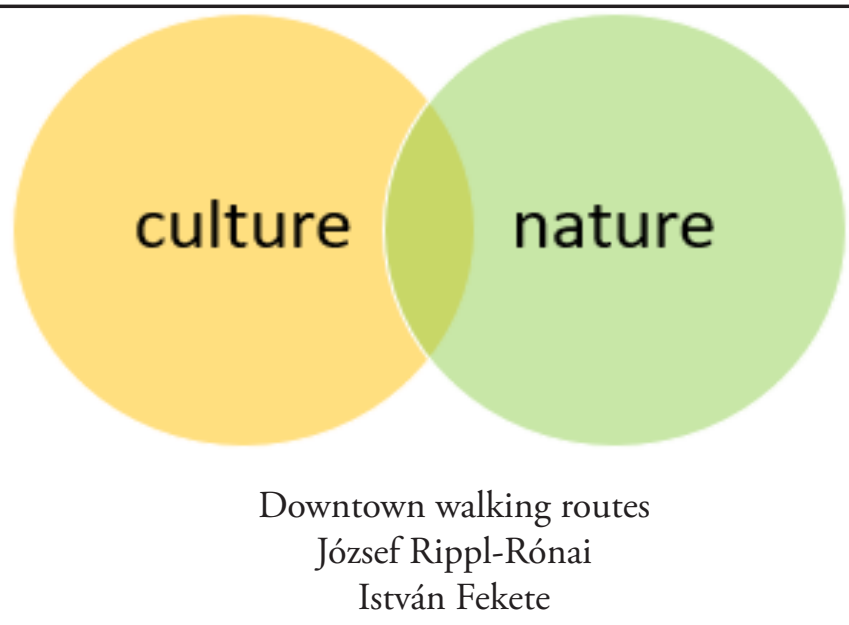

János Vaszary

Zselic

Csiky Gergely Theatre

Lake Deseda

Kaposfest

Flowerbatch

Nevertheless, due to the complex nature of the core values, they cannot be clearly separated, their connection is complicated, there is an intersection of the two. The sub-brand of Rippl-Rónai is a good example: while the artistic heritage of the painter is a cultural factor, rethinking the park of his late residence already belongs to the theme of nature and recreation. The reproduction of one of his paintings from flowers has been planted according to a huge pattern made from his work. 
The strategy provides recommendations not only about the ways of communicating the tourist attractions and the core values they represent, but on their operation and contents to improve the experience they can give their visitors. Due to a relative shortage of human resources, a municipality cannot control or instruct product development activity behind the adventures, it can set out recommendations in order to guide their actions properly.

\section{Physique of the Kaposvár brand}

Although, according to Kapferer, physique is probably the most important feature of the identity of a brand, due to its complex nature, it is not easily demonstrable in a place product. However, Kaposvár brand is still under construction, therefore, its physique is the most easily analysable aspect of its brand identity prism.

Kevin Lynch wrote his book "The Image of the City" in 1960, in which he concludes that the settlements primarily appear as graphic depictions, images in the consumer's mind. According to the urbanist author, the visitors of a city make mental maps based on their perceptions of built environment and orient themselves by the help of them. There are five main types of the built environment: paths, edges, districts, nodes, landmarks (Lynch, 1960).

The key notion of Lynch's book is so-called legibility: by this, the author compares three metropolises (Los Angeles, Boston and Jersey City) examining how easily the mental maps they result in a human mind can be read. "In the process of way-finding, the strategic link is the environmental image, the generalized mental picture of the exterior physical world that is held by an individual. This image is the product both of immediate sensation and of the memory of past experience, and it is used to interpret information and to guide action" (Lynch, 1960). Consequently, a management of a settlement can form the city image consciously constructing its built environment.

Nevertheless, a city may also be successful in shaping its image by conceptually communicating its given physique, its already existing built environment. Kaposvár tried to exploit this academic experience during the development of its own uniform, corporate visual identity: the city logo forms a $\mathrm{K}$ letter, the initial of the settlement's name, while it consists of the pictographic depictions of the building of the main square. The basic graphic elements of the corporate visual identity use the simplified projection of the environment of the downtown built in the art nouveau and classical-style, thus enforcing "the image of the city" in the Lynchian sense as well. Yellow cobblestones are probably the most particular elements of the urban walking routes which the city branding strategy of Kaposvár mentions. The municipality is going to change 100 normal grey-coloured cobblestones, scattered throughout the whole city centre, to yellow ones. These new stones will decorate the paving stone surfaces, and give the essential information about the mysterious history of the nearest building. The image thus can be shaped, organized and amplified according to the intentions of the city management.

The visual conception of the branding strategy of Kaposvár also appointed ITC Garamond and MB Empire to be the official typefaces of the city. ITC Garamond 
is a classical-look serif font, which thus refers to the elegance of a town with more than 300 years of history, MB Empire is a modern-look, grotesque, sans serif typeface, which thereby creates an association with youthfulness and mobility. Corporate colours, Pantone Yellow C and Pantone 282 C dark blue are based on tradition. The flag and the coat of arms of Kaposvár have been including both shades for a very long time. The colour yellow can be also related to Rippl-Rónai, whose favourite colour - according to his journal entry about the zinnias in his garden from 1911 was chrome yellow. Therefore, this up-to-date shade of yellow associates culture with nature, and both with the administrative traditions of the city.

\section{Personality of the Kaposvár brand: cooperativeness and the mayor as the brand ambassador}

It is ambiguously considered by different authors what Kapferer meant by the personality of a brand identity. Some marketing experts propose brand managers to choose a brand ambassador who represent the nature and attitude of the brand, while others suggest a kind of impersonation of the brand to disclose its real personality (Azoulay) and Kapferer, 2003).

Personification of a place brand is quite a complex issue as different target groups find different types of personalities attractive. While tourists expect openness, helpfulness and hospitability, local residents require cooperativeness and orderliness, investors look for diligence, qualifiedness, educatedness, effectiveness and hard-working nature.

A SWOT-analysis from 2016 shows that the mayor Károly Szita's awareness is extremely high (Infinit Média, 2015). Being the mayor of a settlement for the longest period in Hungary, his name is strongly connected to that of the city - this characterises not just the target group of local residents but the tourists and investors as well irrespective of their political views. This fact points out the intricate connection between city branding and political marketing: none of them can exist or operate without the other.

Clean and flowery Kaposvár was considered to be a political slogan for the elections at the beginning of the 2000's, but it became cornerstone of the city's marketing activity in the following one and a half decades, therefore, city branding strategy could not leave it out either in 2016. The motto obviously refers to the tidy and near-nature character of Kaposvár.

Cooperativeness could be a main attribute of the humane Kaposvár. The city management emphasizes that the population of the city works together for their aims, and that is the main reason for the successful development of the settlement. Accordingly, this can be considered as a political mean, but it unquestionably characterises the city marketing activity as well.

\section{Culture of the Kaposvár brand: the folklore of Zselic and Rippl-Rónai}

The brand culture is also an important factor, which is about how the brand interprets the world around them, and how it defines its own role in it. Culture around the 
brand is an important area of its differentiation, as the ideology and values broadcast by the brand can have a big impact on consumer judgement.

Several associations which belong to this area of Kapferer's brand identity prism are linked to the brand's place of origin. In the case of a place product place of origin is the physical place itself, while brand culture is the culture in which local residents live their everyday life. In this sense the culture of Kaposvár brand can be defined as a special segment of Hungarian culture. The place of origin of Kaposvár brand is the South Transdanubian region and more precisely Somogy County and the Zselic district, which, of course, has its own special values among the national ones.

The countryside in Zselic is one of nature's wonders. Being one of the least light polluted areas in the world, it is the perfect destination for those interested in the starry sky. The Star Park of Zselic provides an experience with its expert staff, observatory, telescopes and programmes organised on a regular basis. This experience is unique throughout the country; therefore, it is suitable for being a main focus during the brand positioning process. The small villages dotted in the Zselic area have their own special values. The deer farm in Bőszénfa, the Europa Nostra Award winning Ethnographic museum in Szenna or the adventure farm in Patca all represent the special cultural values mentioned above.

Motivation-based segmentation is the basis of the destination image building, because it determines the preferences, motivations, leisure spending habits of the target group whose members find the Zselic and Kaposvár attractive destinations, in comparison with competitors. According to the consumer insight of the image audit in 2011, the potential target audience is primarily composed by child- and family-centered, active, hospitable people who are interested in local traditions, culture and discoverable values (EconoConsult, 2011).

Therefore, in the case of the Kaposvár brand, culture does not only serve as the background of it - it also provides a strong factor in positioning as well: Rippl-Rónai's lifework is probably the most powerful endorsed brand of Kaposvár. His oeuvre offers a wide range of opportunities in a visual sense, his hedonistic lifestyle gives diverse and abundant source material for the storytelling activity, moving the whole branding process forward in this way.

Arriving at the Rippl-Rónai mansion on Róma Hill, visitors may barely feel anything from the original atmosphere, therefore, the attraction needs a very considerate improvement, since it should offer a memorable experience to its guests. Even the signage system of the mansion or the visitors' centre do not have a uniform design. Experience-oriented interactive instruments would make the enormous cultural heritage more comprehensible thus attracting a lot of interest.

Souvenirs are also crucial components of the sub-brand. The painter's most famous works are adaptable to a great variety of gift items at a wide array of qualities - from a simple mug, a postcard, a shopping bag through an umbrella or a handkerchief to an expensive premium quality perfume with the name of Rippl-Rónai's wife, Lazarine. 
In May 2016, visitors of Kaposvár could see an exhibition of Rippl-Rónai’s paintings from his "corn kernels" period - although, not in a traditional museum or gallery space, but on twenty billboards placed along the main roads leading to the city. This was the first thematically organised exhibition in Hungary appearing on advertising boards. Along with the paintings, elements of the city's new identity also appeared on the posters. Increasing the conceptual nature of the campaign, souvenirs were produced in accordance with the visual language of the exhibition. Unlike the traditional way of purchasing gift items in a museum shop, Rippl-Rónai souvenirs were distributed by a street vendor during the Rippl-Rónai Festival in Kaposvár. This open-air exhibition concept was the first milestone in the creation of a strong Rippl-Rónai brand. During the coming years, a number of creative and awareness-raising campaigns are going to follow this unusual exhibition.

\section{Relationship of the Kaposvár brand}

According to Kapferer's theory, brands function as a relationship that expresses the nature of connection between them and their customers. Being a complex place product, Kaposvár cannot communicate the same quality of relationship towards its all target groups, nevertheless, the city has its own voice with each of them.

Every fourth local resident has his/her own Kaposvár Card which provides a wide range of discounts. The municipality introduced the card in September 2005. The number of discount providers is constantly increasing, not to mention the number of cardholders, which now means almost 23,000 people. High popularity is not accidental, in addition to the opportunity of material savings, the card has now become the symbol of local patriotism for thousands of people living in Kaposvar. The card offers itself with the slogan The city with you (Veled a Város), which makes an attempt to evoke a feeling in the consumers' (i.e. cardholders') mind that they are accompanied by the whole city, and may belong to the community of Kaposvár particularly because a permanent residence card (certification of domicile) is required for owning a Kaposvár Card.

The relationship facet also appears in the touristic events and programmes of Kaposvár. As the main brand strongly builds on Rippl-Rónai's cultural heritage, it almost goes without saying that one of the biggest festivals organized by the municipality bears the name of the famous painter. Rippl-Rónai Festival uses the slogan Rippl paints with you (originally Rippl Veled Fest - which is built on the similarity of word forms between the Hungarian word "fest", which means paints, and the word "fest", which is a shorter version of the word "festival"), which also refers to the friendly nature of the relationship between the city and its visitors.

Friendship appears in the settlement's communication with its potential future investors as well. The brochure entitled Reasons for Kaposvár includes a pair of pages in which readers may be informed about the opportunities, the special benefits and supports guaranteed for those who would like to invest in Kaposvár. Here the text mentions the settlement as a friend of investors. 
To conclude, the municipality presents itself as a friend of its consumers from all the three target groups.

\section{Reflection of the Kaposvár brand}

Every brand has its own typical consumer, a type of person who potentially wants to choose the product. But Kapferer goes further: according to his theory, there is a type of person who wants to be a type of person by using the product. The brand works like a mirror which shows its desired picture or image to the consumer standing in front of it. The author calls it reflection of the brand. Kapferer warns his reader against mixing the notions of reflection and target up (Kapferer, 2008).

Although further examination would be able to define the Kapfererian reflection, as for now, we only have the result of the image audit on Kaposvár conducted in 2011 which defined the potential touristic target group of the city: middle-aged, high-income person, who travels with a partner or in a group of friends, likes to spend his/her frequent holidays variously, but typically with cultural or gastronomical programs. Monuments, museums, galleries and other attractions are dominant in its motivation, complemented by other cultural programs (i.e. theatre, concerts) as well as bathing, trips and walks. This is now excessively broad, therefore, Kapferer's prism provides a good opportunity in a future image audit on Kaposvár.

\section{Self-image of the Kaposvár brand}

The possible reflections of Kaposvár have not been measured yet. We still do not know anything about the self-image of the consumer evoked by it. It cannot be defined what kind of self-image will be built in the consumer by using the services of the city.

Nevertheless, there were several attempts in the former marketing activity of the city which were to exploit the opportunities provided by this facet of the brand prism. The slogan, for example, which the city used to promote itself, was quite talkative in this sense: Kaposvár, the city of opportunities. This motto was intended to awaken the image that the consumer can build a successful future in Kaposvár, where one may fully realize oneself.

Kaposvár's international chamber music festival, the Kaposfest uses the slogan Freedom of joy which is also to refer to the opportunity of being free, and enjoy music and the rhythm of the city without borders.

\section{CONCLUSIONS}

We can conclude that it may be stated that the system or structure, which the six facets of Kapferer's brand identity prism offers, would be able to make Kaposvár brand more attractive among its target groups. However, it is needed to be added that the city brand is still under construction, moreover, shortage of human resources and the stuffy, narrow-minded approach of many participants of the branding process still create barriers to it. Nevertheless, product development is a much longer process in the case of a place product where the complexity of different services requires a longer period to change (Garamhegyi and Boros, 2009). 
It is clearly visible that Florek and Janiszewska's concerns proved to be unfounded, and - in spite of its complexity and synthetic nature - the prism is applicable to place brands as well. However, the method needs a completed and fully formed brand, and in the case of a Kaposvár-scale settlement, this evolution of such an image takes much more time than in case of a normal tangible product or an intangible but more clearly defined service.

\section{ACKNOWLEDGEMENTS}

This project was supported by EFOP-3.6.1-16-2016-00007 „Intelligens szakosodási program a Kaposvári Egyetemen” at the Kaposvár University.

\section{REFERENCES}

Anholt, S. (2010): Definitions of place branding - Working towards a resolution. In: Place Branding and Public Diplomacy 6. 1. 1-10. p. doi: 10.1057/pb.2010.3

Azoulay, A., Kapferer, J-N. (2003): Do brand personality scales really measure brand personality? In: Brand Management 11. 2. 143-155. p.

doi: $10.1057 /$ palgrave.bm.2540162

Bauer A., Kolos K. (2016): Márkamenedzsment. Budapest: Akadémiai Kiadó, 300 p. ISBN: 9789630597449

EconoConsult (2011): Image of Kaposvár and the Zselic destination - search report. Budapest: EconoConsult Kft.

Florek, M., Janiszewska, K. (2013): Defining place brand identity: Methods and deter-minants of application. In: Actual Problems of Economics 150.12. 543-553. p.

Garamhegyi Á. (2004): A településmarketing mint a nonbusiness marketing egy esete. In: Dinya, L., Farkas, F., Hetesi, E., Veres, Z. (Eds.): Nonbusiness marketing és menedzsment. Budapest: KJK-Kerszöv. 271-285. p. ISBN: 9799632247877

Garamhegyi Á., Boros L. (2009): Bevezetés a településmarketingbe. Szeged: JATE Press. ISBN: 9789633150184

Hankinson, G. (2015): Rethinking the Place Branding Construct. In: Kavaratzis, M., Warnaby, G., Asworth G.J. (Eds.): Rethinking Place Branding - Comprehensive Brand Development for Cities and Regions. Switzerland: Springer, 13-31. p. doi: 10.1007/978-3-319-12424-7_2

Hospers, G.-J. (2011): City branding and the Tourist Gaze. In: Dinnie, K. (Ed.): City Branding: Theory and Cases. London: Palgrave Macmillan, 2011. 29-34. p. doi: 10.1057/9780230294790_4

Infinit Média (2015): Kaposvár mindig zöldebb. Stratégiai javaslat megvalósításra Kaposvár Megyei Jogú Város számára. Budapest: Infinit Média Kft.

Janiszewska, K., Insch, A. (2012): The Strategic Importance of Brand Positioning in the Place Brand Concept - Elements, Structure and Application of the Positioning Statement. In: Journal of International Studies, 5. 1., 9-19. p.

doi: $10.14254 / 2071-8330.2012 / 5-1 / 2$ 
Kapferer, J-N. (2008): The New Strategic Brand Management. London: Kogan Page. 560. p. ISBN: 9780749465155

Kavaratzis, M. (2004): From city marketing to city branding: Towards a theoretical framework for developing city brands. In: Place Branding 1. 1. 58-73. p. doi: $10.1057 /$ palgrave.pb.5990005

Kozma G. (1995): Városmarketing mint a helyi gazdaságfejlesztés egyik lehetséges eszköze. In: Tér és Társadalom, 9. 1-2.37-54. p. doi: 10.17649/TET.9.1-2.326

Lackó L. (1995): Települési ismeretek. Budapest: Államigazgatási Főiskola

Lynch, D. (1960): The Image of the City. Boston: M.I.T. Press. 194. p. ISBN: 0-26262001-4

Papp-Váry Á. (2017): “Mondj kevesebbet!” - A sikeres várospozicionálás alapjai. Oral lecture. Regional and City Marketing Section, Conference on Brand Building. Telekom headquarters, Budapest. 30 May 2017.

Piskóti I. (2012): Régió- és településmarketing. Budapest: Akadémiai Kiadó. 400. p. ISBN: 9789630591867

Törőcsik M. (2011): Fogyasztói magatartás - insight, trendek, vásárlók. Budapest: Akadémiai Kiadó. 499. p. ISBN: 9789630591584

Utazok.hu (n.d.): Szállás és Utazás: Barangolás a Zselic dombjai között. [online] <URL: http://www.utazok.hu/latnivalok/Szenna/barangolas-a-zselic-dombjai-kozott $/ 350>$

Corresponding author:

\section{Kristóf Kovács}

Kaposvár University, Faculty of Economic Science

H-7400 Kaposvár, Guba Sándor u. 40.

e-mail: kovacs.kristof@ke.hu

(c) Copyright 2020 by the authors.

This is an open access article under the terms and conditions of the

Creative Commons attribution (CC-BY-NC-ND) license 4.0.

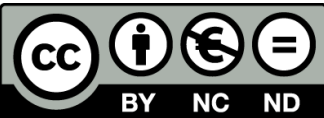

